\title{
Study on Genetic Variability, Heritability, Genetic Advance and Correlation among different characters in tomato (Solanum lycopersicum L.)
}

\author{
Harpal Singh, Dr. Daljeet Singh
}

\begin{abstract}
Department of Vegetable Science, University College of Agriculture, Guru Kashi University,Talwandi Sabo (Bathinda),Punjab, India

Email: harpaldhaliwal@hotmail.com
\end{abstract}

\begin{abstract}
The present investigation entitled "Studies on genetic variability in tomato (Solanum lycopersicum L.)" was carried out at the UCOA, vegetable research farm, Guru Kashi University, Talwandi Sabo, Bathinda during rabi 2015-16 to evaluate tomato genotypes. The experiment was laid out in CRD with three replications. Total 20 genotypes including check cultivar were evaluated for horticultural Traits contributing yield and quality (suitable for processing). There is a wide variability in different genotypes in tomato. Traits i.e. Number of primary branches per plant, Days to first fruit harvest, Plant height (cm), number of fruits per cluster, number fruits per plant, average fruit weight $(\mathrm{gm})$, equatorial diameter of fruit $(\mathrm{cm})$, polar diameter of fruit (cm), number of locules per fruit, pericarp thickness (mm), fruit $\mathrm{pH}$, Fruit TSS $\left({ }^{\circ}\right.$ brix), days to last fruit harvest and average yield per plant $(\mathrm{kg})$ were studied during the investigation Analysis of variance showed significant differences among genotypes for all the characters under study during the investigation. High Phenotypic and Genotypic coefficient of variation were detected for characters like number of fruits per plant, number of locules per fruit, pericarp thickness and average yield per plant. High heritability coupled with genetic gain were recorded for number of fruits per plant, average fruit weight, number of locules per fruit and average yield per plant. Therefore these characters also show some scope for improvement through selection. A highly significant and positive phenotypic and genotypic correlation were found in number of fruits per cluster, plant height, number of fruits per plant and average fruit weight.
\end{abstract}

Keywords-Tomato, Genotypes. Acc number, Traits, Heritability, Locules.

\section{INTRODUCTION}

Tomato (Solanum lycopersicum L.) is the member of family solanaceae. Tomato is one of the most popular vegetable grown all over the world both for fresh markets and processing industry. It is grown practically in open fields, green houses and net houses. Among the vegetable production it ranks third after potato and sweet potato, however it ranks first in first in processed vegetable. China followed by India, USA, Spain and Egypt are leading tomato producing countries. In India during the year 201516 according to $3^{\text {rd }}$ advanced estimates the area under tomato cultivation is 760.0 thousand hectare with the production and productivity of 18399.0 thousand million tonnes and 24.2 million tonnes per hectare respectively . Whereas during the year 2014-15 the area under tomato cultivation was 767 thousand hectare and the production 16985.0 million tonnnes with the productivity of 21.4 million tonnes per hectare. In Punjab the area under tomato cultivation was 7.6 thousand hectare with the production and productivity of 181.1 million tonnes and 24.5 million tonnes per hectare respectively (Ministry of agriculture and farmers welfare, Govt of India). This is low as comparative to the average productivity globally.

Tomato being a self pollinated crop, it has a tremendous potential for heterosis breeding and it is used in different breeding programmes. Variability in tomato is expected to be immense as the fruits vary greatly in shape and size (Bhard waj and Sharma, 2005). To imp rove the productivity of tomato, the primary consideration should be to bring out genetic improvement of the crop and development of superior varieties by selection among and within the population through the use of available genetic variability. As yield is the main objective of a breeder, it is important to know the relationship between various characters those contribute to the yield. The degree of relationship or 
association of these characters with the yield can be known by correlation studies. Genetic parameters such as Genotypic and Phenotypic coefficient of variation (GCV and PCV) are useful in detection of variability present in genotypes available. Heritability and genetic advance help in determining the influence of environment in determining the influence of environment in expression of the characters and the extent to which improvement is possible after selection (H.F. Robinson et. al., 1949). Therefore the investigation was carried out in to mato with the objective to estimate phenotypic coefficient of variation, genotypic coefficient of variation, heritability, genetic advance, correlation coefficient.

\section{MATERIAL AND METHOD}

The investigation was carried out during the rabi season of 2015-16 at the vegetable research farm of Guru Kashi University, Talwandi Sabo (Bathinda). The experimental material consisted of 20 genotypes along with check cultivar i.e. Punjab Chhuhara. The experiment was laid out in completely randomizes design (CRD) with three replications in each treatment. Plants were transplanted on $3^{\text {rd }}$ Dec, 2015 at the plant to plant spacing of $30 \mathrm{~cm}$ in plot having size of $3.0 \mathrm{~m}^{2}$, accommodating 10 plants per plot. During the experiment data was recorded for 14 different characters. The Genotypic and phenotypic coefficients of variation were calculated as per the method suggested by Burton and De Vane (1953). Heritability (in broad sense) and genetic gain was calculated as per suggested by Allard (1960). Whereas correlation coefficient values were calculated as per given by Fishers and Yates (1963).

\subsection{Genetic variability}

\section{RESULTS AND DISCUSSION}

The analysis of variance indicated significantly higher amount of variability among the genotypes for all the characters studied during the investigation. This showed that there is a great scope foe selection of breeding material to initiate any breeding programmme for crop improvement. But to know the absolute extent of variability the phenotypic coeffic ient of variance and genotypic coefficient of variance was calculated.

The Phenotypic coefficient of variance was found higher magnitude than genotypic coefficient of variance for all the character under the study, though the difference was very less under the majority of the cases. Phenotypic coefficient of variance was high for character like number of fru its per plant (40.92\%), Number of locules per fruit (38.05\%), Average fruit yield per plant $(37.52 \%$, Pericarp thickness
$(32.81 \%)$ and while moderate for No of fruits per cluster $(28.59 \%)$, Average fruit weight $(28.56 \%)$, No of primary branches per plant $(23.09 \%)$, Polar diameter of fruit (19.07\%), Plant height (18.58) and Fruit TSS (18.07). Low values of phenotypic coefficient of variation were observed in Equatorial fruit diameter (12.36\%), Fruit pH (5.15), Days to first fruit harvest $(3.62 \%)$, Days to last fruit harvest $(3.34 \%)$. Whereas Genotypic coefficient of variance was high Genotypic coeffic ient of variation (Table 4.3) was high for characters like No of fru its per plant (35.88\%), Average yield per plant $(35.88 \%)$ and No of locules per Fruit $(34.17 \%)$, while moderate for Average fruit weight (28.20\%), Plant height $(18.11 \%)$, Pericarp thickness $(16.87 \%)$, Polar diameter of fruit $(16.76 \%)$, No of fruits per cluster $(15.62 \%)$ and Fruit TSS $(15.37 \%)$. Low values of phenotypic coefficient of variation were observed in No of primary branches per plant (13.73\%), Equatorial diameter of fruit $(9.10 \%)$, Fruit $\mathrm{pH}(3.42 \%)$, Days to first fruit harvest (3.36\%) and days to last fruit harvest (2.91\%).

\subsection{Heritability}

The estimates of heritability varied from 26.43 to $97.52 \%$ for different characters under study (Table 4.3). It was high for characters like Average fruit weight (97.52\%), Plant height (95.06\%), Number of fruits per plant (94.64\%), Average yield per plant $(91.46 \%)$, Days to first fruit harvest $(85.80 \%)$ and No of locules per fruit (80.65\%), while moderate for Polar diameter of fru it $(77.26 \%)$, Days to last fruit harvest $(75.80 \%)$, fruit TSS $(72.28 \%)$ and Equatorial diameter of fruit $(54.69 \%)$. Low values of Heritability were observed in Fruit $\mathrm{pH}(44.13 \%)$, Nu mber of fru its per cluster $(36.40 \%)$, No of primary branches per plant $(35.37 \%)$ and Pericarp thickness $(26.43 \%)$.

\subsection{Genetic advance and genetic gain}

The genetic gain (genetic advance expressed as percentage of population mean) was low to high in nature and ranged from 4.62 to $79.20 \%$ (Table 4.3).High genetic gain was recorded for Number of fruits per plant (79.20\%), Average yield per plant, Number of locules per fruit $(63.21 \%)$ and average fruit weight $(57.38 \%)$, while moderate for Plant height $(36.38 \%)$, Polar diameter of fruit $(30.36 \%)$ and Fruit TSS (26.91\%). Low values of genetic gain were observed in number of fruits per cluster $(19.41 \%)$, Pericarp thic kness (17.86\%), Nu mber of primary branches per plant (16.82\%), Equatorial diameter of fruit $(13.86 \%)$, Days to first fruit harvest $(6.40 \%)$, Days to last fruit harvest (5.21\%) and Fruit pH (4.68\%). Kumar et al (2013) also reported High phenotypic coefficient of variability (PCV), genotypic coefficient of variability (GCV) and heritability estimates 
coupled with high genetic gain were recorded for number of fruits per plant, yield per plant and fruit weight.

These results were found in accordance with Bangaru et al. (1983) Reported high GCV and PCV for number of fru its per plant. Mittal et al. (1996) who observed high heritability along with high genetic advance in number of fruits per plant. Aysh et al.(2012) observed Highest GCV and PCV for number of fruits per plant. High heritability for Fruit weight, number of locules per fruit and fruit y ield was reported by Golani et al. (2007).

Table.1: Range, Mean and Genetic parameters for different characters under study in tomato

\begin{tabular}{|c|c|c|c|c|c|c|c|c|c|}
\hline S.No & Characters & & & Mean & $\overline{P C V}$ & GCV & Heritability & Genetic & Genetic \\
\hline & & Max & Min & & & & & & \\
\hline 1. & $\begin{array}{l}\text { Number of } \\
\text { primary } \\
\text { branches }\end{array}$ & 3.0 & 6.0 & 4.62 & 23.09 & 13.73 & 35.37 & 0.78 & 16.82 \\
\hline 2 & $\begin{array}{l}\text { Days of } 1^{\text {st }} \\
\text { fruit harvest }\end{array}$ & 126.33 & 149.66 & 140.07 & 3.62 & 3.36 & 85.80 & 8.97 & 6.40 \\
\hline 3 & Plant height & 51.00 & 95.33 & 74.44 & 18.58 & 18.11 & 95.06 & 27.08 & 36.38 \\
\hline 4 & $\begin{array}{l}\text { Number of } \\
\text { fruits per } \\
\text { cluster }\end{array}$ & 2.33 & 4.33 & 3.14 & 25.89 & 15.62 & 36.40 & 0.61 & 19.41 \\
\hline 5 & $\begin{array}{l}\text { Number of } \\
\text { fruits per } \\
\text { plant }\end{array}$ & 14.00 & 67.00 & 32.31 & 40.62 & 35.88 & 94.64 & 25.59 & 79.20 \\
\hline 6 & $\begin{array}{l}\text { A ver age } \\
\text { fruit weight } \\
\text { (g) }\end{array}$ & 28.0 & 68.38 & 42.88 & 28.56 & 28.20 & 97.52 & 24.61 & 57.38 \\
\hline 7 & $\begin{array}{ll}\text { Total } & \text { yield } \\
\text { per } & \text { plant } \\
(\mathrm{kg}) & \\
\end{array}$ & 0.58 & 2.14 & 1.31 & 37.52 & 35.88 & 91.46 & 0.94 & 70.69 \\
\hline 8 & $\begin{array}{l}\text { Equatorial } \\
\text { diameter of } \\
\text { fruit }(\mathrm{cm})\end{array}$ & 3.76 & 5.46 & 4.55 & 12.36 & 9.10 & 54.69 & 0.63 & 13.86 \\
\hline 9 & $\begin{array}{l}\text { Polar } \\
\text { diameter of } \\
\text { fruit }(\mathrm{cm})\end{array}$ & 3.50 & 6.23 & 5.00 & 19.07 & 16.76 & 77.26 & 1.52 & 30.36 \\
\hline 10 & $\begin{array}{lr}\text { No. } & \text { of } \\
\text { locules per } \\
\text { fruit }\end{array}$ & 2.00 & 5.66 & 3.04 & 38.05 & 34.17 & 80.65 & 1.93 & 63.21 \\
\hline 11 & $\begin{array}{l}\text { Pericarp } \\
\text { thickness } \\
(\mathrm{mm})\end{array}$ & 4.00 & 9.33 & 5.72 & 32.81 & 16.87 & 26.43 & 1.02 & 17.86 \\
\hline 12 & Fruit pH & 3.56 & 4.16 & 3.87 & 5.15 & 3.42 & 44.13 & 0.18 & 4.68 \\
\hline 13 & $\begin{array}{ll}\text { Fruit } & \text { TSS } \\
\text { (Brix) } & \\
\end{array}$ & 2.80 & 5.36 & 3.86 & 18.07 & 15.37 & 72.28 & 1.04 & 26.91 \\
\hline 14 & $\begin{array}{l}\text { Days to last } \\
\text { fruit } \\
\text { Harvest }\end{array}$ & 153.33 & 175.67 & 166.73 & 3.34 & 2.91 & 75.80 & 8.69 & 5.21 \\
\hline
\end{tabular}




\subsection{Studies of correlation.}

The correlation studies carried out during the investigation show that the in general the genotypic correlations were high than that of phenotypic correlation. In the investigation it was analysed that on the basis of phenotypic correlations among 14 characters (Table 2) showed that fruit yield per plant had positive and significant association with number of fru its per plant (0.7397), plant height (0.4215), number of fru its per cluster (0.4410), average fruit weight $(0.3101)$ and polar diameter (0.2637). Ho wever, it showed significant negative correlation with number of day to first harvest ($0.2795)$ and pericarp thickness $(-0.2688)$.

Number of fruits per cluster had significant positive correlation with number of fru its per plant (0.4477).Nu mber of primary branches had significant positive correlation with fru it TSS (0.3207)and day to first harvest (0.2534), it showed significant negative correlation with fruit $\mathrm{pH}$ (0.3033). Days to first fruit harvest had significant positive correlation with days to last fruit harvest (0.8538) and no. of locules per fruit (0.2621) and negative correlation with no. of fruits per plant (-0.4599).Plant height had significant positive correlation with equitorial diameter of fruit (0.3441), average fruit weight (0.3092), no. of locules per fruit (0.2893) and negative correlation with fruit $\mathrm{pH}$ ($0.2613)$. Number of fruit per plant had significant negative correlation with average fruit weight (-0.3599) and days to last fruit harvest (-0.2705).Average fruit weight had significant positive correlation with polar diameter $(0.5991)$ and equatorial diameter (0.5778). Equitorial diameter had significant positive correlation with no. of locules per fruit (0.4568), polar diameter (0.2978), and fruit TSS (0.2952) and fruit $\mathrm{pH}$ (0.2652). Polar diameter had significant negative correlation with no. of locules per fruit (0.5133). No. flocules per fruit had significant positive correlation with fruit TSS (0.3473).

Whereas the study of genotypic correlations among 14 characters under investigation show that fruit y ield per plant had positive and significant association with number of fruits per cluster (0.6489), plant height (0.4390), average fruit weight (0.3148) and polar diameter (0.2736). However, it showed significant negative correlation with number of day to first harvest $(-0.2956)$ and pericarp thickness (-0.5330).

Number of fruits per cluster had significant positive correlation with number of fruits per plant (0.7002), pericarp thickness (0.5379), fruit $\mathrm{pH}(0.3348)$, plant height (0.3271) and no. of locules per fruit (0.2571).Number of primary branches had significant positive correlation with fruit TSS (0.5322), day to first harvest (0.4785), plant height (0.3777), average fruit weight $(0.3353)$ and days to last fruit harvest (0.3114), it showed significant negative correlation with fruit $\mathrm{pH}(-0.5793)$ and no. of fruits per plant (-0.3304).Days to first fruit harvest had significant positive correlation with days to last fruit harvest (0.9072), fruit TSS (0.3068), equatorial diameter $(0.2745)$ and no. of locules per fruit (0.2626) and negative correlation with polar diameter (-0.2743).Plant height had significant positive correlation with equitorial diameter of fruit (0.4306), no. of locules per fruit (0.3394) and average fruit weight (0.3335) and negative correlation with fruit $\mathrm{pH}(-$ 0.4334). Number of fru it per plant had significant negative correlation with average fruit weight (-0.3648), equatorial diameter (-0.3283) and days to last fruit harvest (0.3124).Average fruit weight had significant positive correlation with polar diameter (0.6501) and equatorial diameter (0.7342). Equitorial diameter had significant positive correlation with no. of locules per fruit (0.6150), fruit $\mathrm{pH}(0.4399)$ and fru it TSS (0.4022). Polar diameter had significant positive correlation with fruit $\mathrm{pH}(0.2705)$ and negative correlation with no. of locules per fruit (0.6025), pericarp thickness (-0.5960) and days to last fruit harvest (-0.3092).Number of locules per fruit had significant positive correlation with fruit TSS $(0.5333)$ and pericarp thickness (0.4258).Pericarp thickness had significant positive correlation with fru it TSS $(0.3710)$. The estimates of genotypic and phenotypic correlation coefficients imparted that the genotypic correlation were higher magnitude than the corresponding phenotypic ones for most of the character combinations, thereby establishing predominant role of heritable factor.

The results those were carried out for correlation studies during the invest tigation were found to be in accordance with Singh and Cheema (2006) they observed that genotypic correlations were of higher magnitude than the corresponding phenotypic correlation values for most of the character combinations in tomato which were similar to results of correlation among different characters in the investigation carried out. The results also corroborated with the results carried out by Pradheep et al (2007) for correlation for fruits per plant, fruit weight and fruit yield. The results were also found to be in accordance with those of Shushay et al (2014) fru it yield and number of fruits per plant. The results for correlation studies were also in accordance the results carried out by Golani et al. (2007) for nu mber of primary branches and number of locules per fruit. 
Table: 2 Phenotypic and Genotypic correlation of different characters of tomato

\begin{tabular}{|c|c|c|c|c|c|c|c|c|c|c|c|c|c|c|c|}
\hline Characters & & $\begin{array}{l}\begin{array}{l}\text { No } \\
\text { fruit }\end{array} \\
\text { s } \\
\text { per } \\
\text { clust } \\
\text { er }\end{array}$ & $\begin{array}{l}\text { No } \\
\text { primary } \\
\text { branche } \\
\text { S }\end{array}$ & $\begin{array}{l}\text { Days to } \\
\text { first } \\
\text { harvest }\end{array}$ & $\begin{array}{l}\text { Plant } \\
\text { height }\end{array}$ & $\begin{array}{l}\text { No of fruits } \\
\text { per plant }\end{array}$ & $\begin{array}{l}\text { Average } \\
\text { fruit } \\
\text { weight } \\
\text { (g) }\end{array}$ & $\begin{array}{l}\text { Equatori } \\
\text { al } \\
\text { diameter } \\
(\mathrm{cm})\end{array}$ & $\begin{array}{l}\text { Polar } \\
\text { diameter } \\
(\mathrm{cm})\end{array}$ & $\begin{array}{l}\text { No of } \\
\text { locules } \\
\text { per fruit }\end{array}$ & $\begin{array}{l}\text { Pericarp } \\
\text { thickness } \\
(\mathbf{m m})\end{array}$ & $\begin{array}{l}\text { Fruit } \\
\text { pH }\end{array}$ & $\begin{array}{l}\text { Fruit } \\
\text { TSS } \\
\text { (Brix) }\end{array}$ & $\begin{array}{l}\text { Days to } \\
\text { Last } \\
\text { fruit } \\
\text { harvest }\end{array}$ & $\begin{array}{l}\text { Average } \\
\text { yield per } \\
\text { plant (kg) }\end{array}$ \\
\hline \multirow{2}{*}{$\begin{array}{l}\text { No fruits } \\
\text { per cluster }\end{array}$} & $\mathrm{P}$ & & -0.1501 & -0.0921 & .01728 & $0.4477 * *$ & -0.386 & 0.1086 & 0.0184 & 0.1239 & 0.1334 & -0.0174 & -0.0537 & -0.0579 & $0.4410^{* *}$ \\
\hline & $\mathrm{G}$ & & $\begin{array}{l}- \\
0.4429 * \\
*\end{array}$ & -0.1235 & $0.3271^{*}$ & $0.7002 * *$ & -0.0995 & 0.1833 & -0.0110 & $0.2571^{*}$ & $0.5379^{* *}$ & $\begin{array}{l}0.3348^{*} \\
*\end{array}$ & -0.0276 & -0.0420 & $0.6489 * *$ \\
\hline \multirow{2}{*}{$\begin{array}{l}\text { No } \\
\text { primary } \\
\text { branches }\end{array}$} & $\mathrm{P}$ & & & $0.2534^{*}$ & 0.2145 & -0.2025 & 0.1810 & -0.0276 & -0.0481 & 0.0986 & 0.1158 & $-0.3033^{*}$ & $0.3207 *$ & 0.1711 & -0.0277 \\
\hline & $\mathrm{G}$ & & & $\begin{array}{l}0.4785^{*} \\
*\end{array}$ & $\begin{array}{l}0.3777^{*} \\
*\end{array}$ & $-0.3304 * *$ & $0.3353^{* *}$ & 0.1008 & -0.1113 & 0.1843 & 0.1589 & $\begin{array}{l}- \\
0.5793 * \\
*\end{array}$ & $\begin{array}{l}0.5322 * \\
*\end{array}$ & $\begin{array}{l}0.3114 \\
*\end{array}$ & -0.0525 \\
\hline \multirow{2}{*}{$\begin{array}{l}\text { Days to } \\
\text { first } \\
\text { harvest }\end{array}$} & $\mathrm{P}$ & & & & 0.0817 & $-0.4599 * *$ & 0.1556 & 0.1421 & -0.2116 & $0.2621 *$ & 0.0762 & 0.0375 & 0.2255 & $\begin{array}{l}0.8538 \\
* *\end{array}$ & $-0.2795^{*}$ \\
\hline & $\mathrm{G}$ & & & & 0.0920 & -0.2120 & 0.1789 & $0.2745^{*}$ & $-0.2743^{*}$ & $0.2626^{*}$ & 0.1938 & 0.0204 & $0.3068^{*}$ & $\begin{array}{l}0.9072 \\
* *\end{array}$ & $-0.2956^{*}$ \\
\hline \multirow{2}{*}{$\begin{array}{l}\text { Plant } \\
\text { height }\end{array}$} & $\mathrm{P}$ & & & & & 0.1166 & $0.3092 *$ & $0.3441^{* *}$ & -0.0371 & $0.2893^{*}$ & -0.0495 & $-0.2613^{*}$ & 0.0547 & 0.0462 & $0.4215 * *$ \\
\hline & $\mathrm{G}$ & & & & & 0.1083 & $0.3335^{* *}$ & $0.4306^{* *}$ & -0.0734 & $\begin{array}{l}0.3394 * \\
*\end{array}$ & -0.0758 & $\begin{array}{l}- \\
0.4334 * \\
*\end{array}$ & 0.0640 & 0.0707 & $0.4390 * *$ \\
\hline \multirow[t]{2}{*}{$\begin{array}{l}\text { No of fruits } \\
\text { per plant }\end{array}$} & $\bar{P}$ & & & & & & $-0.3599 * *$ & 0.2383 & -0.1331 & 0.0872 & -0.1201 & -0.1183 & -0.0786 & $\begin{array}{l}- \\
0.2705 \\
*\end{array}$ & $0.7397 * *$ \\
\hline & $\mathrm{G}$ & & & & & & $-0.3648 * *$ & $-0.3283^{* *}$ & -0.1438 & 0.0794 & -0.2300 & -0.1315 & -0.0728 & $\begin{array}{l}- \\
0.3124 \\
* *\end{array}$ & 0.2487 \\
\hline \multirow{2}{*}{$\begin{array}{l}\text { Average } \\
\text { fruit } \\
\text { weight } \\
\text { (gm) }\end{array}$} & $\mathrm{P}$ & & & & & & & $0.5778^{* *}$ & $0.5991 * *$ & 0.0557 & -0.1678 & -0.0179 & 0.1117 & 0.0752 & $0.3101 *$ \\
\hline & $\mathrm{G}$ & & & & & & & $0.7342 * *$ & $0.6501 * *$ & 0.0744 & $-0.4599 * *$ & -0.0551 & 0.1059 & 0.0794 & $0.3148^{*}$ \\
\hline $\begin{array}{l}\text { Equatorial } \\
\text { diameter } \\
(\mathrm{cm})\end{array}$ & $\mathrm{P}$ & & & & & & & & $0.2978^{*}$ & $\begin{array}{l}0.4568^{*} \\
*\end{array}$ & 0.1183 & $0.2652^{*}$ & $0.2952^{*}$ & 0.0990 & 0.1809 \\
\hline Polar & $\mathrm{P}$ & & & & & & & & & - & -0.2148 & 0.1655 & -0.0834 & -0.2009 & $0.2637^{*}$ \\
\hline
\end{tabular}


International Journal of Environment, Agriculture and Biotechnology (IJEAB)

http://dx.doi.org/10.22161/ijeab/3.4.8

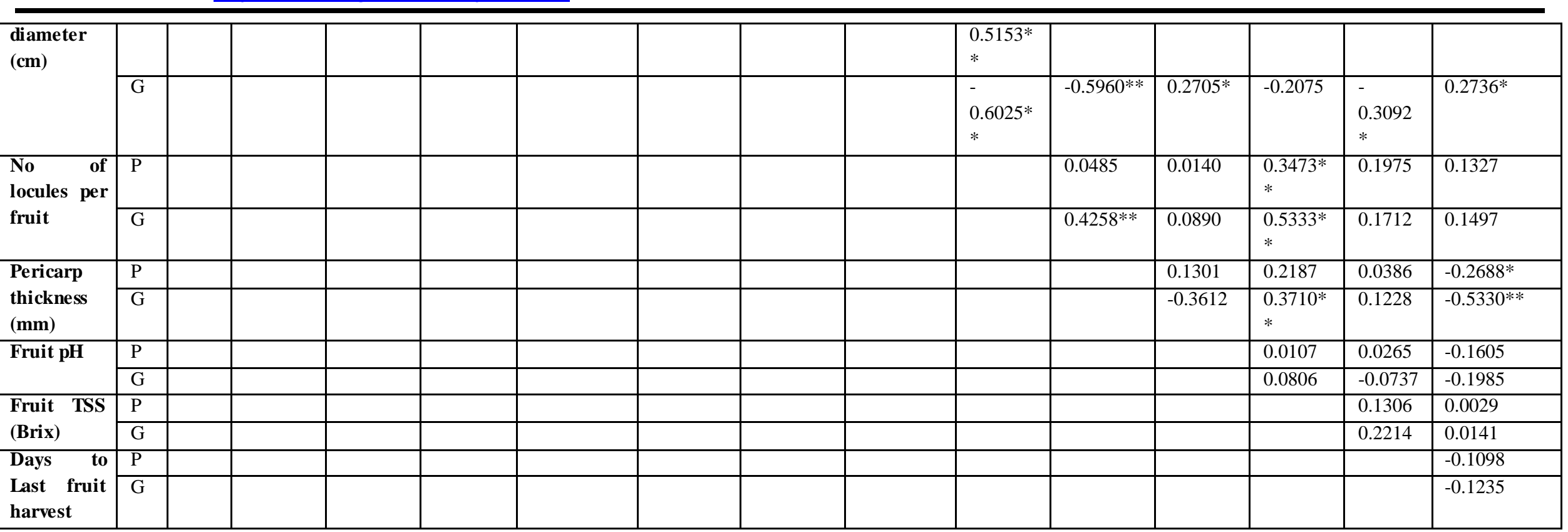




\section{REFERENCES}

[1] Allard, R.W., 1960. Principle of Plant Breeding. John Wiley and Sons Inc., New York, USA.

[2] Aysh, AlF, Serhan Al M, Shareef Al A, Nasser Al and Kutma M H. (2012). Study of genetic parameters and character interrelationship of yield and some yield components in tomato (Solanum lycopersicum L.). International Journal ofGenetics 2(2): 29-33.

[3] Bangaru, C., Muthukrishnan, C.R and Irulappan, I (1983) Genetic variation in $F_{2}$ generation of to mato. Madras agric. J. 70:349-350.

[4] Bhardwaj, N.V., Sharma, M.K. 2005: Genetic parameters and character association in tomato. Bangladesh Journal of Agricultural Research, 30 (1) 49-56.

[5] Burton, G.W and De Vane, E.H (1953).Estimating heritability in tall fescue (Festuca arundinancce) from replicated clonal materials. Agron. J.45:515-518.

[6] Fisher, R. A., and Yates, Y., 1963. Statistical tables for biological, agricultural and medicinal research. Edinberg: Oliver and Boyd, Ltd.

[7] Golani, I.J., Mehta, D.R., Purohit, V.L., Pandya, H.M. and Kanzariya, M.V., 2007: Genetic Variability, Correlation and path coefficient studies in tomato. Indian journal of agricultural research, 41(2): 146149

[8] H. F. Robinson, R. E. Comstock and P. H. Harvey, 1949: Estimates of heritability and degree of dominance in corn, Agronomy Journal, 41, 253-259

[9] Ministry of agriculture and farmers welfare, Govt. of India

[10] Mittal, Pankaj, Parkesh, Sant and Singh, A.k. (1966). Variability studies in tomato (Lycopersicon esculentum Mill) under sub humid conditions of Himachal Pradesh. South Indian Horticulture, 44(5\&6): 132-134.

[11] Pradheep, K., Veeragavathatham, D. and Auxcilia (2007). Correlation analysis in tomato (Lycopersicon esculentum Mill) with emphasis on virus resistance. South Indian Horticulture, 55 (1-6): 12-19

[12] Singh, H. and cheema, D.S (2006). Correlation and path coefficient studies in tomato. Haryana J. Hortic. Sci., 35(1\&2):126-129

[13] Shushay .C and Haile Z., 2014. Evaluation of tomato varieties for fruit yield and yield components Northern Ethiopia. Int. J. of .Agri. Res., 10:23-39. 